\title{
PENGEMBANGAN PROGRAM LAYANAN BIMBINGAN DAN KONSELING KOMPREHENSIF DI SMA
}

\author{
Luky Kurniawan \\ Bimbingan dan Konseling, Universitas Negeri Yogyakarta \\ email: lukymen_049@yahoo.co.id
}

\begin{abstract}
The research program is aimed at generating a comprehensive guidance and counseling services in the school to be used by teachers in the high school guidance and counseling. This research is the development of a descriptive use of the procedural model. Using the procedure of development of Borg and Gall. Two groups of subjects validation program is two expert guidance and counseling programs, principals and teachers group guidance and counseling in high school. Data collection techniques used were questionnaires and Focus Group Discussion (FGD). Data were analyzed descriptively qualitative and quantitative. Programs of comprehensive guidance and counseling services is produced through a two-stage and two-stage validation program revisions. Expert validation results indicate that the program of comprehensive guidance and counseling services in high school had a decent implemented with some revisions based on advice, as a whole can be categorized either. While the results of Focus Group Discussion (FGD) program of comprehensive guidance and counseling services in high school was approved to be implemented with some revision of the results of the discussion.
\end{abstract}

Keywords: Developing comprehensive guidance and counseling services program.

Abstrak: Penelitian bertujuan menghasilkan program layanan bimbingan dan konseling komprehensif di SMA untuk dapat digunakan oleh guru bimbingan dan konseling di SMA. Penelitian ini merupakan penelitian pengembangan menggunakan model prosedural bersifat deskriptif. Menggunakan prosedur pengembangan Borg and Gall. Dua kelompok subyek validasi program adalah dua ahli program bimbingan dan konseling, kepala sekolah dan kelompok guru bimbingan dan konseling di SMA. Teknik pengumpulan data yang digunakan adalah angket dan Focus Group Discussion (FGD). Data dianalisis secara deskriptif kualitatif dan kuantitatif. Program layanan bimbingan dan konseling komprehensif dihasilkan melalui dua tahap validasi program dan dua tahap revisi. Hasil validasi ahli menunjukkan bahwa program layanan bimbingan dan konseling komprehensif di SMA telah layak diimplementasikan dengan beberapa revisi sesuai saran, secara keseluruhan dapat dikategorikan baik. Sedangkan hasil Focus Group Discussion (FGD) program layanan bimbingan dan konseling komprehensif di SMA disetujui untuk diimplementasikan dengan beberapa revisi hasil diskusi.

Kata kunci: Pengembangan, program layanan bimbingan dan konseling komprehensif. 


\section{PENDAHULUAN}

Sasaran utama subyek pendidikan adalah peserta didik, yang dalam praktiknya peserta didik harus dipandang kedudukannya sebagai subyek dan obyek sekaligus. Sebagai subyek peserta didik harus ditempatkan sebagai individu-individu yang memiliki hak-haknya sebagai pribadi (manusia secara utuh). Sebagai obyek peserta didik harus berbuat sesuai dengan kewajibannya untuk mencapai optimalisasi perkembangannya baik yang menyangkut aspek kognitif, afektif, dan psikomotorik. Peserta didik mempunyai potensi-potensi yang dapat dikembangkan dan kebutuhan materiil, spiritual yang harus dipenuhi. Menurut Havighurst (Monks dkk, 2002: 22), tugas perkembangan (developpmental task) yaitu tugas yang harus dilakukan oleh individu dalam masa hidup tertentu sesuai dengan norma masyarakat dan norma kebudayaan. Peserta didik akan merasa sedih bila tidak dapat melaksanakan tugas perkembangan dengan baik, sebaliknya keberhasilan dalam melaksanakan tugas perkembangan memberikan perasaan berhasil dan akhirnya perasaan bahagia. Dalam melaksanakan tugas perkembangan dan memenuhi kebutuhan materiil spiritual peserta didik akan menemui masalah-masalah tetapi kompleksitas masalah-masalah yang dihadapi individu yang satu dengan yang lainnya berbedabeda (Rohmat Mulyana, 2005: 210).

Dengan memahami karakteristik tersebut konselor dapat memilih pendekatan dan teknik yang tepat dalam memperlakukan peserta didik sebagai manusia dan mengetahui kebutuhankebutuhan peserta didik. Perlakuan yang tepat untuk memenuhi kebutuhan peserta didik adalah merelevansikan program (Ridwan, 2008: 109). Kegiatan-kegiatan bimbingan dan konseling di sekolah diwujudkan dalam suatu program yang terorganisir dan terencana. Program bimbingan dan konseling akan terselenggara secara efektif, apabila didasarkan kebutuhan nyata dan kondisi obyektif perkembangan peserta didik. Menurut Ridwan (Saring Marsudi, 2003: 23), bimbingan dan konseling yang bermakna adalah bimbingan dan konseling yang memberikan manfaat sepenuhnya bagi subyek. Oleh karena itu layanan bimbingan dan konseling hendaknya berdasar pada kebutuhan subyek. Hal ini berimplikasi dalam penyusunan program, program hendaknya disusun dengan diawali menganalisis kebutuhan (needs assessment). Hal tersebut dipertegas oleh temuan penelitian dari Sunaryo Kartadinata, dkk (1996-1999) yang menunjukkan bahwa program bimbingan dan konseling di sekolah akan berlangsung efektif, apabila didasarkan kepada kebutuhan nyata dan kondisi objektif perkembangan peserta didik (Syamsu Yusuf dan Juntika Nurihsan, 2003: 1).

Bimbingan dan konseling dikenal sebagai suatu layanan untuk peserta didik di sekolah. Bimbingan dan konseling merupakan ilmu yang bergerak dalam bidang human services. Bantuan psikologis diberikan oleh konselor atau pembimbing dengan maksud membentuk individu agar dapat mengembangkan potensi dirinya atau mencapai tugas-tugas perkem-bangan.

Tujuan utama layanan bimbingan dan konseling di sekolah adalah memberikan dukungan pada pencapaian kematangan kepribadian, keterampilan sosial, kemampuan akademik, dan bermuara pada terbentuknya kematangan karir individual yang diharapkan dapat bermanfaat di masa yang akan datang (Fatur Rahman, 2009: 4). Namun demikian, implementasi layanan bimbingan dan konseling yang ideal tersebut berhadapan dengan berbagai hambatan dan sejumlah kendala serius. Berbagai hambatan dan kendala tersebut, seperti: tujuan bimbingan dan konseling tidak selaras dengan tujuan pendidikan, bimbingan dan konseling masih berorientasi pada masalah, penyusunan program belum berdasarkan needs assessment, minimnya dukungan dari pejabat sekolah terha-dap program bimbingan dan konseling, belum dipahaminya paradigma hubungan kolaborasi antar profesi dalam satuan pendidikan dan kurang adanya respon yang positif dari peserta didik terhadap layanan bimbingan dan konseling. Berdasarkan review beberapa Perangkat Administrasi Bimbingan dan Konseling SMA di Yogyakarta yang dilakukan peneliti dapat disimpulkan, bahwa penyusunan program layanan bimbingan dan konseling di SMA belum berdasarkan needs assessment, minimnya hubungan kolaborasif antar staf maupun antar profesi dan tidak adanya jam masuk kelas bagi guru bimbingan dan konseling di SMA. Ketidakpastian dalam penyelenggaraan bimbingan dan konseling di sekolah selama ini, seperti penyelenggaraan bimbingan dan konseling yang dalam kurikulum tingkat satuan pendidikan dan kurikulum 2013 belum terakomodir dengan baik, 
sehingga pelaksanaan bimbingan dan konseling di SMA diselenggarakan dengan pola yang tidak jelas.

Ketidakjelasan pola yang harus diterapkan berdampak pada buruknya citra bimbingan dan konseling. Pertanyaan yang berkecamuk dibenak para guru bimbingan dan konseling SMA di Yogyakarta adalah bagaimana seharusnya penyelenggaraan bimbingan dan konseling di sekolah dilaksanakan?

Menurut Resminingsih (2010), sebagai salah satu profesi yang memberikan layanan sosial atau layanan kemanusiaan maka secara sadar atau tidak keberadaan profesi bimbingan dan konseling berhadapan dengan perubahan realitas baik yang menyangkut perubahan-perubahan pemikiran, persepsi, demikian juga nilai-nilai. Perubahan yang terus menerus terjadi dalam kehidupan, mendorong konselor perlu mengembangkan awareness, pemahaman, dan penerapannya dalam perilaku serta keinginan untuk belajar, dengan diikuti kemampuan untuk membantu peserta didik memenuhi kebutuhan yang serupa. Konselor akan menjadi agen perubahan serta pembelajar yang bersifat kontinyu. Layanan Bimbingan dan Konseling menjadi sangat penting karena langsung berhubungan langsung dengan peserta didik. Hubungan ini tentunya akan semakin berkembang pada hubungan peserta didik dengan peserta didik lain, guru dan karyawan, orang tua/keluarga, dan teman-teman lain di rumah.

Menurut Depdiknas (2007: 194), pada saat ini telah terjadi perubahan paradigma pendekatan bimbingan dan konseling, yaitu dari pendekatan yang berorientasi tradisional, remedial, klinis, dan terpusat pada konselor, kepada pendekatan yang berorientasi perkembangan dan preventif. Pendekatan bimbingan dan konseling perkembangan (Developmental Guidance and counseling) atau bimbingan dan konseling komprehensif (Comprehensive Guidance and Counseling) didasarkan pada upaya pencapaian tugas perkembangan, pengembangan potensi, dan pengentasan masalah-masalah konseli. Tugas-tugas perkembangan dirumuskan sebagai standar kompetensi yang harus dicapai konseli, sehingga pendekatan ini disebut juga bimbingan dan konseling berbasis standar (Standard Based Guidance and Counseling). Ketika pendekatan bimbingan dan konseling perkembangan dipergunakan akan menggabungkan pendekatan yang berorientasi klinis, remidial, dan preventif, (Myrick, 1993: 8).

Lima premis dasar yang menegaskan istilah Comprehensive school guidance and counseling yang harus dipahami sebagai kerangka kerja utuh oleh tenaga-tenaga ahli di bidang bimbingan dan konseling karena lima premis dasar ini adalah sebagai titik tolak untuk mengembangkan program dan mengelola bimbingan dan konseling di sekolah. Menurut Gysbers \& Henderson (Fathur Rahman, 2009: 2), lima premis dasar yang menegaskan istilah Comprehensive school guidance and counseling adalah; a) Tujuan Bimbingan dan konseling bersifat kompatibel dengan tujuan pendidikan. Dalam pendidikan ada standar dan kompetensi tertentu yang harus dicapai oleh peserta didik. Oleh karena itu, segala aktivitas dan proses dalam layanan bimbingan dan konseling harus diarahkan pada upaya membantu peserta didik dalam pencapaian standar kompetensi yang dimaksud., b) Program bimbingan dan konseling bersifat pengembangan (based on developmental approach). Meskipun seorang konselor dimungkinkan untuk mengatasi problem dan kebutuhan psikologis yang bersifat krisis dan klinis, pada dasarnya fokus layanan bimbingan dan konseling lebih diarahkan pada usaha memfasilitasi pengalaman-pengalaman belajar tertentu yang membantu peserta didik untuk tumbuh, berkembang, dan menjadi pribadi yang mandiri., c) Program bimbingan dan konseling melibatkan kolaborasi antar staf (team-building approach). Program bimbingan dan konseling yang bersifat komprehensif bersandar pada asumsi bahwa tanggung jawab kegiatan bimbingan dan konseling melibatkan seluruh personalia yang ada di sekolah dengan sentral koordinasi dan tanggung jawab ada di tangan konselor yang bersertifikat (certified counselors). Konselor tidak hanya menyediakan layanan langsung untuk peserta didik, tetapi juga bekerja konsultatif dan kolaboratif dengan tim bimbingan yang lain. Staf personel sekolah (guru dan tenaga administrasi), orang tua dan masyarakat. Hal ini hampir sama dengan yang diutarakan oleh Myrick (1993: 11) yang menjelaskan bahwa pendekatan bimbingan dan konseling harus lebih berorientasi kepada pengembangan siswa, yang merupakan usaha untuk mengidentifikasi keahlian dan pengalaman yang perlu dimiliki siswa agar berhasil di sekolah., d) Program bimbingan dan konseling 
dikembangkan melalui serangkaian proses sistematis sejak dari perencanaan, desain, implementasi, evaluasi, dan keberlanjutan. Melalui penerapan fungsi-fungsi manajemen tersebut diharapkan kegiatan layanan bimbingan dan konseling dapat diselenggarakan secara tepat sasaran dan terukur., f) Program bimbingan dan konseling ditopang oleh kepemimpinan yang kokoh. Faktor kepemimpinan ini diharapkan dapat menjamin akuntabilitas dan pencapaian kinerja program bimbingan dan konseling.

Model bimbingan dan konseling Komprehensif terdapat tiga unsur dan empat komponen. Tiga Unsur tersebut meliputi isi dari program, kerangka yang organisatoris, dan sumber daya. Isi meliputi kemampuan siswa. Kerangka mempunyai tiga komponen struktural (definisi, asumsi, dan dasar pemikiran) dan empat komponen program (guidance curriculum, individual planning, responsive services, and system support). Unsur Sumber daya menyertakan personil, anggaran dana, dan mengimplementasikan program. Bimbingan dan konseling komprehensif mempunyai komponen yang menyertakan aktivitas dan tanggung-jawab dari semua yang terlibat dalam program bimbingan dan konseling komprehensif (Cobia \& Henderson, 2009: 61).

Lebih lanjut menurut Bowers \& Hatch (Fathur Rahman, 2009: 3), menyatakan bahwa program bimbingan dan konseling sekolah tidak hanya bersifat komprehensif dalam ruang lingkup, namun juga harus bersifat preventif dalam desain, dan bersifat pengembangan dalam tujuan (comprehensive in scope, preventive in design and developmental in nature). Pertama, bersifat komprehensif berarti program bimbingan dan konseling harus mampu memfasilitasi capaian-capaian perkembangan psikologis siswa dalam totalitas aspek bimbingan (pribadi-sosial, akademik, dan karir). Layanan bimbingan dan konseling di tujukan untuk seluruh siswa tanpa syarat apapun. Kedua, bersifat preventif dalam disain mengandung arti bahwa pada dasarnya tujuan pengembangan program bimbingan dan konseling di sekolah hendaknya dilakukan dalam bentuk yang bersifat preventif. Upaya pencegahan dan antisipasi sedini mungkin (preventive education) hendaknya menjadi semangat utama yang terkandung dalam pelayanan dasar (guidance curriculum) yang diterapkan sekolah. Melalui cara yang preventif tersebut diharapkan siswa mampu memilah tindakan dan sikap yang tepat dan mendukung pencapaian perkembangan psikologis kearah ideal dan positif. Beberapa program yang dapat dikembangkan seperti pendidikan multikultarisme dan anti kekerasan, mengembangkan keterampilan resolusi konflik, pendidikan seksualitas, kesehatan reproduksi, dan sebagainya, Ketiga, bersifat pengembangan dalam tujuan bahwa program yang didisain konselor sekolah bertujuan untuk memenuhi kebutuhan para peserta didik sesuai dengan tahap perkembangan.

Menurut Depdiknas (2007:220-223), penyu-sunan program bimbingan dan konseling di sekolah dimulai dari kegiatan asesmen, atau kegiatan mengidentifikasi aspek-aspek yang dijadikan bahan masukan bagi penyusunan program tersebut. Asesmen adalah aktivitas fondasi bagi pengembangan program yang akuntabel (Gibson \& Mitchell, 2008: 567). Kegiatan asesmen ini meliputi (1) asesmen lingkungan, yang terkait dengan kegiatan mengidentifikasi harapan sekolah dan masyarakat (orang tua peserta didik), sarana dan prasarana pendukung program bimbingan, kondisi dan kualifikasi konselor, dan kebijakan pimpinan sekolah; dan (2) asesmen kebutuhan atau masalah peserta didik, yang menyangkut peserta didik, seperti aspek fisik (kesehatan dan keberfungsinya), kecerdasan, motif belajar, sikap dan kebiasaan belajar, minat-minatnya (pekerjaan, jurusan, olah raga, seni, dan keagamaan), masalah-masalah yang dialami, dan kepribadian; atau tugas-tugas perkembangan sebagai landasan untuk memberikan pelayanan bimbingan dan konseling.

Struktur pengembangan program bimbingan dan konseling komprehensif menurut

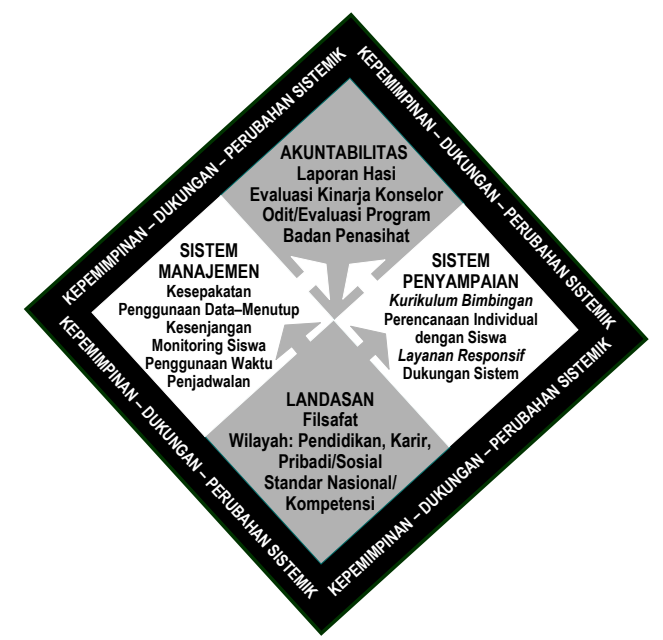


American School Counselor Association (ASCA) sebagai berikut:

\section{Gambar 1. School Counseling Program Structure}

(American School Counselor Association, 2005: 20).

Dari hasil studi pendahuluan yang dilakukan oleh peneliti terhadap 40 siswa SMA Negeri di Yogyakarta dapat disimpulkan, bahwa siswa menganggap guru bimbingan dan konseling sebagai polisi sekolah yang bertugas menangani "anak-anak bermasalah" dan bertugas memberikan skoring pelanggaran tata tertib yang dilakukan oleh peserta didik. Pola sikap negatif dan kenakalan peserta didik pada umumnya seringkali dianggap sebagai dampak dari kurang berfungsinya layanan bimbingan dan konseling di sekolah. Selain itu, pola sikap negatif dan kenakalan peserta didik juga disebabkan oleh tidak disusunnya program layanan bimbingan dan konseling secara terencana dan sitematis di sekolah. Di sisi lain, ada sebagian siswa yang menganggap guru bimbingan dan konseling sebagai figur yang membantu siswa agar dapat mencapai perkembangan secara optimal sesuai dengan bakat, kemampuan, minat dan nilai-nilai, serta terpecahkan masalah-masalah yang dihadapi peserta didik. Hal tersebut terlihat, ada beberapa siswa yang datang sendiri ke ruang bimbingan dan konseling tanpa dipanggil terlebih dahulu.

Pemilihan program layanan bimbingan dan konseling komprehensif sebagai pola layanan yang akan dikembangkan di SMA, karena program layanan bimbingan dan konseling komprehensif memiliki kelebihan dibanding dengan pola lama. Kelebihan itu salah satunya adalah program layanan bimbingan dan konseling komprehensif bersifat sistemik, bukan sekedar program yang sistematis. Program bimbingan dan konseling yang sistematis adalah program pelaksanaannya sesuai dengan rencana, tertata baik sejak perencanaan, pendataan, implementasi dan evaluasi. Sementara sifat sistemik program bimbingan dan konseling komprehensif nampak pada beberapa hal seperti, penyusunan program bimbingan dan konseling diawali dengan needs assesment, layanan bimbingan dan konseling menjangkau seluruh peserta didik, program bimbingan dan konseling melibatkan kolaborasi antar staf maupun profesi dalam satuan pendidikan, evaluasi yang dilakukan mencakup tiga jenis evaluasi yaitu evaluasi kinerja konselor (counselor perfomance evaluation), evaluasi program dan evaluasi hasil (result evaluation).

Berdasarkan paparan di atas, peneliti menganggap perlu untuk melakukan pengembangan program layanan bimbingan dan konseling komprehensif. Oleh karena itu pengadaan program layanan bimbingan dan konseling komprehensif sangat diperlukan sebagai salah satu penunjang tercapainya visi/misi yang ada di sekolah secara khusus dan tujuan pendidikan nasional pada umumnya. Penelitian ini bertujuan menghasilkan program layanan bimbingan dan konseling komprehensif yang layak digunakan sebagai pedoman penyelenggaraan layanan bimbingan dan konseling di SMA.

\section{METODE}

Penelitian ini merupakan penelitian pengembangan (Research and Development) dengan menggunakan model prosedural yang bersifat deskriptif yaitu menggariskan langkahlangkah yang harus diikuti untuk menghasilkan produk. Produk yang dimaksud dalam pengembangan ini adalah program hipotetik layanan bimbingan dan konseling komprehensif.

Penelitian pengembangan dilaksanakan di SMA N 1 Depok Sleman Yogyakarta. Prosedur pengembangan yang akan dilalui dalam penelitian dan pengembangan program layanan bimbingan dan konseling komprehensif di SMA Negeri 1 Depok Sleman Yogyakarta menggunakan prosedur pengembangan Borg and Gall sebagai berikut: 1) Penelitian Awal dan Pengumpulan Data, (a) Analisis kebutuhan (needs assessment), peneliti mengumpulkan data berkenaan dengan program layanan bimbingan dan konseling komprehensif di sekolah tempat penelitian., (b) Merumuskan Masalah, rumusan masalah dalam pengembangan ini adalah belum adanya sebuah program layanan bimbingan dan konseling yang sesuai dengan kebutuhan nyata dan kondisi obyektif yang dapat digunakan sebagai pedoman guru bimbingan dan konseling dalam menyelenggarakan layanan bimbingan dan konseling., (c) Studi literatur, peneliti mempelajari konsep-konsep atau teori-teori yang berkenaan dengan program layanan bimbingan dan konseling komprehensif yang akan dikembangkan., (d) Perencanaan., (e) 
Pengembangan program awal., 2) Pengembangan program, (a) Validasi ahli, draft awal program layanan bimbingan dan konseling komprehensif akan dievaluasi oleh beberapa ahli untuk mendapatkan masukan, tanggapan, serta kritik dan saran sebagai bahan revisi program yang dikembangkan. (b) FGD (Focus Group Discussion), draft program layanan bimbingan dan koseling komprehensif yang telah di validasi ahli kemudian didiskusikan dengan kepala sekolah dan kelompok guru bimbingan dan konseling di SMA Negeri 1 Depok Sleman Yogyakarta untuk mendapatkan penyempurnaan dan penyesuaian keadaan di SMA Negeri 1 Depok Sleman Yogyakarta. (c) Program final, program final adalah program hipotetik layanan bimbingan dan konseling komprehensif yang dibuat berdasarkan hasil validasi, diskusi, analisis, dan revisi.

Teknik pengumpulan data yang digunakan untuk penelitian ini adalah angket dan Focus Group Discussion (FGD). Data dianalisis secara deskriptif kualitatif dan kuantitatif. Program layanan bimbingan dan konseling komprehensif ini dihasilkan melalui dua tahap validasi program dan dua tahap revisi.

Data-data yang diperoleh dalam pengembangan program layanan bimbingan dan konseling ini berupa data kualitatif dan kuantitatif. Data kuantitatif diperoleh dari angket tertutup sedangkan data kualitatif diperoleh dari hasil validasi ahli dan FGD yang berupa masukan, tanggapan, serta kritik dan saran untuk bahan revisi program yang dikembangkan.

Dua kelompok subyek validasi program dalam penelitian pengembangan ini adalah dua ahli yang berkompeten dalam program bimbingan dan konseling, serta kepala sekolah dan kelompok guru bimbingan dan konseling di SMA.

Teknik analisis data yang digunakan untuk mengolah data yang diperoleh dalam pengembangan program bimbingan dan konseling komprehensif ini adalah dengan menggunakan analisis deskriptif kualitatif dan kuantitatif.

\section{HASIL DAN PEMBAHASAN}

Berdasarkan data kuantitatif hasil penilaian ahli dapat disimpulkan secara umum bahwa program layanan bimbingan dan konseling komprehensif SMA Negeri 1 Depok tahun ajaran 2011/2012 termasuk dalam kategori baik dengan skor $81,96 \%$. Hasil uji ahli dapat diuraikan sebagai berikut:

1. Penilaian terhadap landasan termasuk dalam kategori baik dengan memperoleh nilai ratarata $79,17 \%$, dengan rincian: kejelasan rasional program layanan bimbingan dan konseling 75\% (cukup baik), kesesuaian visi dan misi BK dengan visi dan misi sekolah 75\% (cukup baik), ketepatan deskripsi kebutuhan $75 \%$ (cukup baik), kejelasan deskripsi kebutuhan 75\% (cukup baik), kesesuaian bidang pengembangan dengan deskripsi kebutuhan 100\% (baik), kejelasan tujuan setiap bidang pengembangan $75 \%$ (cukup baik).

2. Penilaian terhadap komponen program termasuk dalam kategori baik dengan memperoleh niali rata-rata $82,81 \%$, dengan rincian: visibilitas bentuk implementasi pelayanan dasar 75\% (cukup baik), kejelasan bentuk implementasi pelayanan dasar $87,5 \%$ (baik), visibilitas bentuk implementasi pelayanan responsif $87,5 \%$ (baik), kejelasan bentuk implementasi pelayanan responsif $75 \%$ (cukup baik), visibilitas bentuk implementasi perencanaan individual 87,5\% (baik), kejelasan bentuk implementasi perencanaan individual $87,5 \%$ (baik), visibilitas bentuk implementasi dukungan sistem 87,5\% (baik), kejelasan bentuk implementasi dukungan sistem 75\% (cukup baik).

3. Penilaian terhadap sistem manajemen termasuk dalam kategori baik dengan memperoleh nilai rata-rata $84,62 \%$, dengan rincian: kejelasan deskripsi tugas personil sekolah, dalam kaitannya dengan bimbingan konseling $75 \%$ (cukup baik), ketepatan pemilihan dewan penasihat $87,5 \%$ (baik), kejelasan data yang akan digunakan $100 \%$ (baik), kesesuaian alokasi waktu pelayanan dasar 87,5\% (baik), kesesuaian alokasi waktu pelayanan responsif $75 \%$ (cukup baik), kesesuaian alokasi waktu perencanaan individual $75 \%$ (cukup baik), kesesuaian alokasi waktu dukungan system 75\% (cukup baik), bentuk program tahunan $87,5 \%$ (baik), kejelasan deskripsi program tahunan $87,5 \%$ (baik), bentuk program bulanan 87,5\% (baik), kejelasan deskripsi program bulanan $87,5 \%$ (baik), bentuk program harian $87,5 \%$ (baik), kejelasan deskripsi program harian $87,5 \%$ (baik). 
4. Penilaian terhadap akuntabilitas termasuk dalam kategori baik dengan memperoleh rata-rata nilai $81,25 \%$, dengan rincian: kejelasan rencana evaluasi $87,5 \%$ (baik), kejelaan prosedur pelaksanaan evaluasi $75 \%$ (baik).

Berdasarkan hasil perhitungan secara kuantitatif di atas, program layanan bimbingan dan konseling komprehensif SMA Negeri 1 Depok yang dikembangkan mendapatkan ratarata penilaian 81,96 dan berdasarkan kriteria keefektifan yang ditetapkan termasuk dalam kategori baik atau layak diimplementasikan. Namun, berdasarkan data kualitatif program ini perlu direvisi sesuai masukan/saran dan komentar dari ahli.

\section{SIMPULAN DAN SARAN}

Proses pengembangan program layanan bimbingan dan konseling komprehensif dilakukan dengan dua tahap validasi program dan dua tahap revisi. Dua tahap validasi program tersebut adalah validasi ahli dan Focus Group Discussion (FGD), sedangkan dua tahap revisi yang dilakukan adalah revisi program tahap pertama berdasarkan validasi ahli dan revisi tahap kedua berdasarkan Focus Group Discussion (FGD).

Program layanan bimbingan dan konseling komprehensif ini dari hasil validasi ahli telah dinyatakan layak diimplementasikan dan termasuk dalam kategori baik, dan dari hasil Focus Group Discussion (FGD) dinyatakan telah layak diimplementasikan.

Struktur program layanan bimbingan dan konseling komprehensif SMA Negeri 1 Depok Sleman Yogyakarta sebagai berikut:

Bagian I Landasan (Foundation)

a. Rasional

b. Visi dan misi

c. Bidang pengembangan

d. Deskripsi kebutuhan (Need assessment)

Bagian II komponen program

a. Pelayanan dasar

b. Pelayanan responsif (Responsif services)

c. Perencanaan individual (Individual students planning)

d. Dukungan system (System support)

Bagian III Sistem manajemen (Management System)

a. Kesepakatan (Agreements) guru bimbingan dan konseling dan personil pendukung bimbingan dan konseling (Kepala Sekolah, Guru Mata Pelajaran, Wali Kelas, dan Staf Administrasi) melaksanakan tugas dalam kaitannya dengan pelayanan bimbingan dan konseling, sesuai dengan fungsi dan peran masing-masing.

b. Dewan penasihat (Advisory council) yang ditunjuk untuk memeriksa hasil pelaksanaan program layanan bimbingan dan konseling komprehensif dan membuat rekomendasi yaitu Kepala Dinas Pendidikan Kabupaten Sleman dan Kepala sekolah SMA Negeri 1 Depok Sleman Yogyakarta.

c. Data (Use of data) yang akan digunakan dalam program layanan bimbingan dan konseling komprehensif di SMA Negeri 1 Depok Sleman Yogyakarta yaitu, Data Pribadi, Instrumen Tugas Perkembangan, Daftar Cek Masalah, Sosiometri, Tes Who Am I, Studi Habit, Presensi Siswa, Rekap Prestasi Belajar, Anecdetol Record, Hasil Wawancara Siswa dan Kartu Konseling.

d. Penggunaan waktu (Use of time) didasarkan kepada isi program dan dukungan manajemen, alokasi waktu untuk peluncuran pelayanan dasar $15 \%$ - 25\%, pelayanan responsif $25 \%-35 \%$, perencanaan individual $25 \%-35 \%$, dukungan sistem $15 \%-20 \%$.

e. Program layanan bimbingan dan konseling komprehensif yang telah dituangkan dalam rencana kegiatan dijadwalkan ke dalam bentuk kalender tahunan, kalender bulanan, dan kalender harian (Calendars).

Bagian IV Akuntabilitas (Accountability system)

a. Rencana evaluasi (program Audit, personnel, results reports)

b. Prosedur pelaksanaan evaluasi

Melalui penelitian ini kami menyarankan

Bagi: Kepala Sekolah,Menyediakan jam masuk kelas secara terjadwal bagi guru bimbingan dan konseling untuk melaksanakan program pelayanan dasar melalui strategi implementasi bimbingan klasikal.

Bagi Guru Bimbingan dan Konseling Mempelajari literatur/bacaan yang relevan dengan bimbingan dan konseling komprehensif agar paham bimbingan dan konseling komprehensif yang diharapkan dapat memperlancar pelaksanaan program layanan bimbingan dan konseling komprehensif di SMA. Melaksanakan, melakukan tindak lanjut dan mempertanggungjawabkan pelaksanaan program 
layanan bimbingan dan konseling komprehensif di SMA. Berkolaborasi dengan guru mata pelajaran dan wali kelas serta pihak-pihak yang terkait dalam pelaksanaan program layanan bimbingan dan konseling komprehensif SMA Negeri 1 Depok Sleman Yogyakarta. Bagi Guru Mata Pelajaran, Wali Kelas dan Staf Administrasi. Guru Mata Pelajaran, wali Kelas dan Staf Administrasi disarankan berpatisipasi aktif dalam membantu pelaksanaan program layanan bimbingan dan konseling komprehensif di SMA.

\section{DAFTAR RUJUKAN}

American School Counselor Association. 2005. The ASCA National Model: A Framework For School Counseling Programs. Second Edition. Alexandria, VA: Author.

Bowers, J. L., \& Hatch, P. A. 2000. The National Model For School counseling Program. American school Counselor association.

Cobia, D. C., \& Henderson, D. A. 2009. Developing An Effective and Accountable School Counseling Program. Second Edition. Upper Saddle River, New Jersey, Columbus, Ohio: Pearson Merrill Prentice Hall.

Departemen Pendidikan Nasional. 2007. Penataan Pendidikan Profesional Konselor dan Layanan Bimbingan Konseling dalam Jalur Pendidikan Formal. Jakarta: Direktorat Jenderal Pendidikan Tinggi.

Fathur Rahman. 2009. Bimbingan dan Konseling Komprehensif; Dari Paradigma Menuju Aksi. Disampaikan pada Workshop Penyusunan Program BK Komprehensif bertempat di Ruang Sidang Utama Rektorat UNY, Kerjasama Prodi BK UNY dan PD ABKIN DIY. Yogyakarta: Universitas Negeri Yogyakarta. . 2009. Reformasi Sekolah dan BK Komprehensif Dalam tinjauan Historis; Kontradiktoris ataukah Komplementaris?. Makalah Seminar Nasional "Pengembangan Pola Layanan Komprehensif Menuju Keselarasan Ideal dan Realita”. Yogyakarta: Universitas Negeri Yogyakarta.

Gibson, R. L., \& Mitchell, M. H. 2008. Introduction to Counseling and Guidance. Upper Saddle River, New Jersey: Pearson Prentice Hall.
Gysbers, J. P., \& Henderson, P. 2006. Developing \& managing Your School Guidance and Counseling Program. Fourth Edition. Alexandria, VA: American Counseling Association.

Myrick, R. D. 1993. Developmental Guidance and Counseling A Practical Approach. Second Edition. Minneapolis, MN: Educational Media Corporation.

Monks, FJ., Knoers, AMP., Siti Rahayu Haditono. 1982. Psikologi Pekermbangan: Pengantar dalam Berbagai Bagiannya. Yogyakarta: Gajah Mada Universitas Press.

Resminingsih. 2010. Layanan Bimbingan Konseling yang Komprehensif dengan Dukungan Teknologi Informasi. (online), tersedia:http://resminingsih.bizweb.co.id/a rticle/detail/layanan-bimbingan-

konseling-yangkomprehensif-dengandukungan-teknologi-informasidisampaikan-dalam-seminar-terbatasolehprodi-bk-fkip-universitas-sanata-dharma, diakses 19 Februari 2010.

Saring Marsudi., dkk. 2003. Layanan Bimbingan Konseling di Sekolah. Surakarta: Muhamadiyah University Press.

Syamsu Yusuf \& A Juntika Nurihsan. 2003. Penyusunan Program Bimbingan dan Konseling Berbasis Perkembangan. Panduan Workshop Bimbingan dan Konseling dalam Acara Konvensi Nasional XIII Asosiasi Bimbingan dan Konseling Indonesia. Bandung: UPI.

Rohmat Mulyana. 2005. Membangun Bangsa Melalui Pendidikan; In Memoriam Prof. Dr. Dedi Supriadi. Bandung: PT Remaja Rosdakarya.

Ridwan. 2008. Penanganan Efektif Bimbingan Konseling di Sekolah. Yogyakarta: $\mathrm{P}$ ustaka Pelajar. 